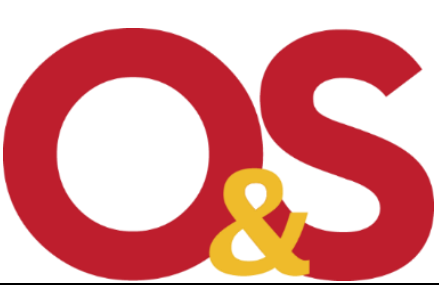

Organizações \& Sociedade Journal

2021, 28(99), 860-887

(C) Authors 2021

DOI 10.1590/1984-92302021v28n9906EN

ISSN 1984-9230

www.revistaoes.ufba.br

NPGA, School of Management

Federal University of Bahia

Associate Editor:

Wescley Xavier

Received: 04/27/2020

Accepted: 03/01/2021

\title{
Rethinking Border Studies: \\ Participation and Social \\ Innovation in Border Zone \\ Development
}

Anderson Luís do Espírito Santo ${ }^{a}$

Douglas Voks ${ }^{\mathrm{a}}$

a Federal University of Mato Grosso do Sul, Corumbá, Brazil

\begin{abstract}
The study of emerging forms of public engagement and collective action is crucial for understanding the ongoing democratic dynamics, citizenship, and the constitution of the city's public problems. To recognize how the field of frontier studies is inseparable from the processes of experience of actors, this study focuses on the importance of the social innovation ecosystem (SIE) for the development of frontier zones. Specifically, this study revisits the main instruments of public management and border development policies to emphasize figures of civil society and their collective mobilizations on the Brazil-Bolivia border, recognizing social innovation initiatives and the main challenges they seek to solve. This path of public investigation allowed us to understand the territorial dimension of borders and expand their meaning as a living space by giving light to the actors' practices, identifying how they mobilize to repair socio-environmental inequalities.
\end{abstract}

Keywords: border studies; social innovation ecosystems; public action; pragmatism; cities. 


\section{Introduction}

The study on public management and border territorial development ${ }^{1}$ (BTD) has mobilized an expressive segment of researchers at national and international level. In Brazil, for example, such interest is revealed mainly by the offer of a professional master's course in border studies (Federal University of Mato Grosso do Sul), by the creation of research centers such as the Unbral Fronteiras ${ }^{2}$, and by holding scientific events dedicated to the theme. These studies are part of a broader movement of geographic renewal, with the amplification of its scope to interdisciplinarity and interculturality, which has been fostering different frontier approaches (Costa \& Oliveira, 2012). The relevance of this subject has gained such value in recent decades that it has conquered space in the public sphere through programs and public policies that aim to promote management, education, and development in border areas. However, the term 'border studies' is still neglected, not being considered as a field of studies in national scientific databases, for example (Cardin \& Albuquerque, 2018). On the contrary, it is considered a stereotype, being thus negligible when central governments develop public policies.

By focusing on the border areas of Latin America, we observe that all countries have gone through dictatorial regimes. Safeguarding their own differences, the histories of these countries walk along a common path, which can be summarized as follows: the colonial period, struggles for independence, the formation of republics and dictatorships, and redemocratization processes. The difficult construction of democracy in Latin America is constantly marked by new dilemmas and public problems, which configure new needs and realities. The will for democracy to be consolidated is enormous (Zaverucha, 2009), being always questioned at the borders. More recently, it has been forged in an era of epidemic walls ${ }^{3}$; with the advance of extreme right-wing conservatism (as in Brazil); by the media's stereotype about borders (Santo, 2018); and by the state's inability to deal with local problems and to stimulate popular participation (Souza, 2006) and, due to their frivolous ideas, to plan development at the borders (Krüger, Dantas, Castro, Passador, \& Caldana, 2017).

Overcoming these problems is a central part of the development process, as we still have 184 million people living in poverty and advancing towards extreme poverty, which already affects 62 million people in Latin America and the Caribbean ("Cepal foresees an increase in the poverty in Latin America and the Caribbean in 2019", 2019). Therefore, we support that through a deliberative and participatory democracy (Cefaï, 2007), such problems can be addressed taking into account the vast repertoires exposed to them aiming at finding the appropriate solution. Democracy in border areas in Latin America should be the expression of freedom or, according to Sen (2000), freedom should be the main means for development, including political freedoms, economic facilities, social opportunities, guarantees of transparency, and protective security. These elements are essential for rethinking border integration and development. However, public policies and other forms of social regulation are generally and largely idealized by central governments (Machado, 1998), as the Brazilian government still does, without the massive participation of civil society in this process, focusing mainly on the subjects of public security and trade agreements.

There are many and profound democratic challenges for countries in their border areas. Through analysis of the public policies created by central governments (Krüger et al., 2017), it can be concluded that "democracy" is confused with "public security" on the border, as this is the main focus of the government agenda. However, this policy is designed for the entire national territory, whose most immediate objective to prevent, among other issues, drugs and other narcotics from 
reaching large cities (Santo, 2018). In other words, it is not a policy that directly affects the quality of life of people living on the border 4 .

Therefore, we agree with the current that believes in valuing local experiences and practices, even if imperfect and incomplete, as the fundamental dawn for the transformation of this reality (Addor, 2018; Andion, Alperstedt, \& Graeff, 2020; Andion, Ronconi, Moraes, Gonsalves, \& Serafim, 2017). We will argue in the next sections that the great challenge is to build objects of public intervention through public action (Lascoumes \& Le Galès, 2012), which is a terminology that seeks to break with the unity of the State and its centralization of decision, giving visibility to the challenges of the city and the efforts of actors to resolve them, promoting participatory comanagement for whatever needs to be faced.

Participation comprises more than the operations of actors in public decisions. We admit that they can be equivalent to participating in worlds of meanings, which are made through the actions of micropublics (Cefaï \& Terzi, 2012). In this logic, public intervention occurs through the actors and their social participation - a fundamental point for the elaboration of policies in a democratic structure. It is up to us researchers to learn more about the different forms of public experience, highlighting the various ways of seeing and communicating with the actors, so that the axes of development on the frontier are expanded further than the necessary public security (addressing subjects such as health, environment, education, tourism, leisure, and others) and in order to idealize a quality of life in this region.

We agree with Addor (2018) on the need to promote "[...] a local political movement that allows the inhabitants to rescue their utopias" (p. 1117). However, we operationalize this view from the contributions by Andion et al. $(2017,2020)$, who supports the identification and analysis of social innovation ecosystems (SIE) promoted by the collective action of civil society in the public sphere from a pragmatist perspective. Social innovations are new ideas and practices that arise from the mobilization of a network of actors who seek to respond to different public problems, such as the quality of life, the insurance of rights, and the fight against poverty and social exclusion (Santo \& Andion, 2020). It is a term that has been gaining strength and attention both in academic literature and in the public discourse. An important reason for this is the greater involvement and participation of civil society in this form of innovation. It addresses putting into practice the emphasis on the action of the actors, so that the democratic spirit is kept alive (Dewey, 1939), seeking to understand the relationship between the collective action undertaken by actors and the city and sustainability (Lévesque, 2009; McPhearson , Andersson, Elmqvist, \& Frantzeskak, 2015; Wolfram \& Frantzeskaki, 2016). Democratic experimentation (Ansell, 2012; Dewey, 1938) is one of the methods used to understand democracy in practice through the experience and action of the actors in the territory ${ }^{5}$.

Given this problematization, we seek to contribute to the reflections made in the field of border studies by answering the following question: what is the importance of recognizing the SIE for the democratic strengthening of border areas? More specifically, we aim to: (a) revisit and identify gaps in the main instruments of public management and border development policies to emphasize the action of actors and their mobilizations; (b) broaden the understanding of the frontier and show the contributions of pragmatism and its association with SIE studies; (c) present the structure of the SIE on the Brazil-Bolivia border, highlighting the different initiatives and public problems they seek to respond to. 
This study presents the first surveys carried out in the Brazil-Bolivia border area, specifically in the cities of Corumbá and Ladário (MS) on the Brazilian side and, on the Bolivian side, in the cities of Puerto Suarez and Puerto Quijarro, in the Germán Busch province, department of Santa Cruz, consisting of a conurbation with approximately 160 thousand inhabitants. In this border, as in most Brazilian borders, the main problems can be summarized in integration and development, as integration is not a priority on the agenda of the Brazilian government (Oliveira et al., 2017), which focuses its development policies mainly on drug trafficking and other illicit activities. Trafficking is part of the border landscape and must be fought (Santo, 2018). However, the idea of development needs to be ground and idealized in view of a social reality and as a political option.

This paper is structured in eight parts. We start from this introduction and the methodological procedure to present three theoretical sections that address management and development in border areas, the field of border studies, and the contributions of the social innovation ecosystem from a pragmatist perspective to this field. Then, we present the main public issues and the structure of the SIEs that have been seeking to promote social change in their area of expertise. We conclude with the final considerations and an indication of the references used in this study.

\section{Research design}

We started this study (theoretical-empirical) with an intense bibliographical and documental survey (research reports and newspapers) on the keywords of this study. This survey took two years (2018-2019) for us to reach the reflections presented in this paper.

Regarding the understanding of social innovation, the formation of SIEs, and their territorial exploration, this study was inspired by the methodology of the Observatory of Social Innovation of Florianópolis (Obisf), a digital and collaborative platform that maps the social innovation networks that are mobilized around public problems in Florianópolis (SC), including support actors, social innovation initiatives, and their interactions.

The Obisf was created in 2017 by researchers from the Santa Catarina State University and is part of a survey consisting of the following four main moments presented in Figure 1: identification of public problems and territorial exploration; mapping of social innovation and support initiatives; ethnography and monitoring of experiences; and the configuration of the SIE and its incidence in the city, which, in order to identify the social innovations underway in the territory, interrelates the following three scales of analysis: macro (institutional), meso (ecosystem), and micro scale (experiences) ${ }^{6}$. 


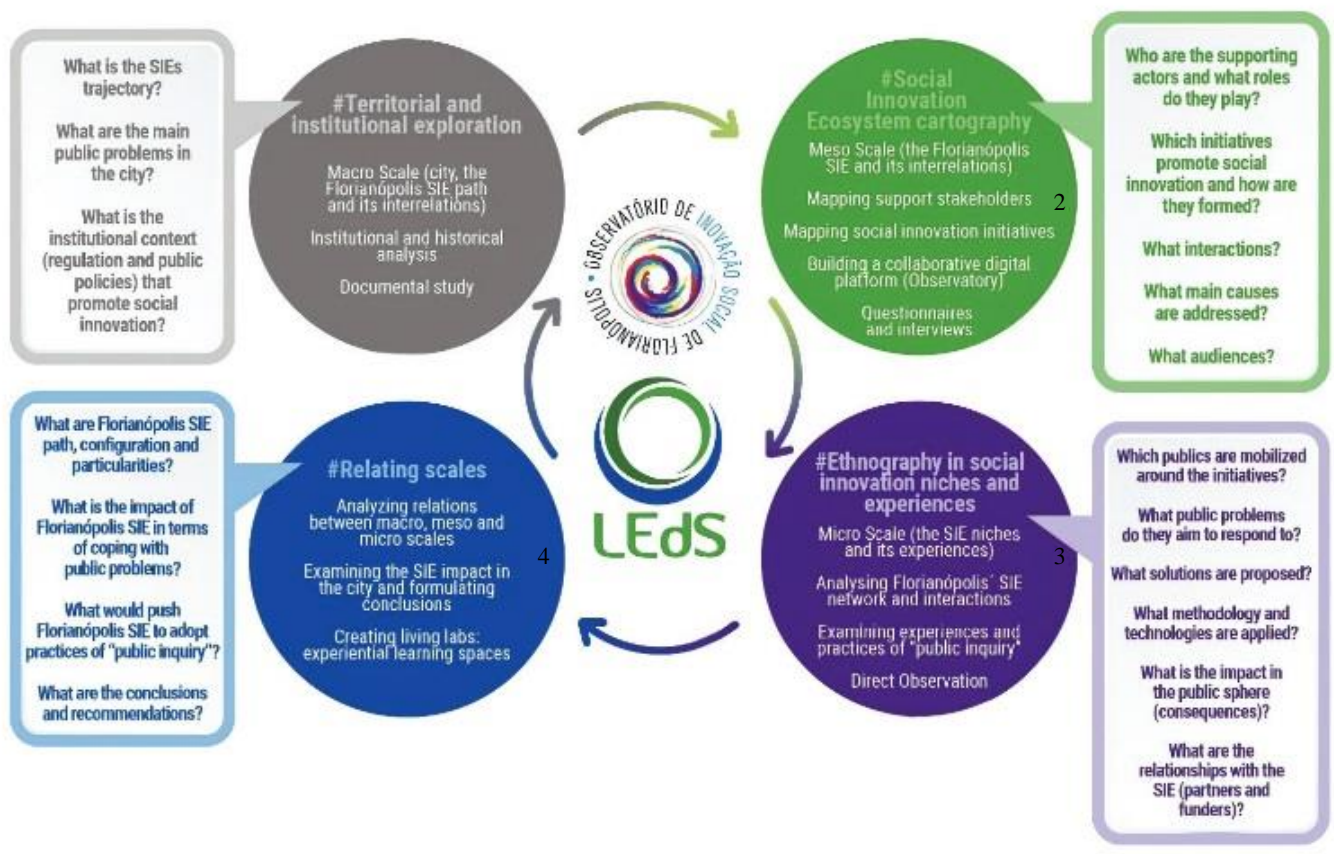

Figure 1. Analytical and methodological framework of Obisf

Source: Andion, Alperstedt,\& Graeff, 2020, p. 195.

Subsequently (2019-2020), the cartography of social innovation and support initiatives present in this frontier was started, which allowed their identification, to perceive the interactions among them, and to recognize the main public problems they seek to solve (moments 1 and 2 of Figure 1). This mapping took place through secondary data (research and document reports). We also had tracked other initiatives, one after another, on the Obisf website, where its partners (initiatives or support actors) are indicated; on the Obisf social network (Instagram or Facebook); or through informal conversations with the managers of some these initiatives. Once identified, it was possible to identify their area of activity, for example: Black Women's Institute of Corumbá; area of expertise: gender and racial and social vulnerability. By recognizing the area of these iniciatives, it was possible to correlate them with one of the 17 Sustainable Development Goals (United Nations, 2015).

Unlike Obisf, which has a digital platform to register its data, we do not have this feature yet. Thus, we used the Google Maps tool to map the SIEs, as this research is the first step of the following broader project: a Center for Border Studies on Social Innovation, which will be the result of this research and is scheduled for release in 2021. What is intended with the project through public investigation is to understand how the actors are mobilized to form a given public and to what extent their actions and experiences affect them and their territory.

Epistemologically, the reading of all these data is based on the trend in sociology of addressing public problems with a pragmatist approach (Andion et al., 2017; Andion et al., 2020; Cefaï, 2009; Cefaï \& Terzi, 2012), consisting of a dialogue with the subjects of social innovation and democratic experimentation (Ansell, 2012; Shields, 2008) to explore the possibilities of new forms 
of organization and to rethink politics through the critical capacity of actors, their practices, and their participation by understanding how action is placed in the border territory.

\section{Scenario and scientific-political debate on border management and development}

When we think on border development and public management, the scenario is quite delicate. Initially, it is worth recognizing the size of the challenge. We are talking about a country that has a border length (BL) ${ }^{7}$ of $15,719 \mathrm{~km}$, bordering ten countries in South America and involving 588 Brazilian municipalities, out of which 121 directly share borders with other countries, that is, being considered as border areas, distributed in 11 Brazilian states. In this length, we have an estimated population of 10 million inhabitants, with Acre having the largest number of inhabitants located in the BL (43\%), followed by Rondônia (38\%), Roraima (22\%), and Mato Grosso do Sul (12\%) (Brazilian Institute of Geography and Statistics, 2018).

Historically, the borders of Brazil were not prioritized by public policies (Machado, 1998), being considered with different interests over time, among which a hegemonic model for development prevailed, as occurred between the 1950s and 1970s, when the so-called 'March to the West' aimed at new ways of accumulating wealth and expanding capitalism towards the South and the Central-West regions, the Amazon, and borders, causing profound transformations and social conflicts in regions of economic expansion (Cardin \& Albuquerque, 2018). The 1970s to the 1980s were also permeated by a flagrant gap between Fordist ideals (Lipietz, 1991), that is, economic, social, and political progress, and the situation of the majority of the population, characterized by the large expansion of inequalities at a global scale (Sachs, 2009). In these areas, the intention was to implement the modernization of the countryside by transferring production techniques and technological innovations to the rural environment due to their prerogative of promoting economic growth and job creation. However, the result further aggravated the situation of the majority of the population in these areas.

For Machado (1998), the governmental disinterest during the decades of 1980-90 - added to the geographical distance, the dominance of the primary sector, the insufficient infrastructure, the low quality of public services, the problems related to poverty and public safety, drug trafficking, and other illicit activities - further aggravated the situation of the population living in border areas. In the 1990s, the increase in policies from development blocks emerged with the aim of further integrating national states. The formation of the European Union (1993), for example, sought to discuss cooperation efforts to rationalize the European production and encourage the dilution of frontiers by unifying the currency and expanding roaming ${ }^{8}$, mobility and its possibilities, tourism, and others. In the case of Mercosur, which seemed to follow a European trajectory, the consolidation of its strategies, forms of cooperation, and other legal-administrative procedures adopted to discuss economic, social, and environmental structures, focused mainly on the economic bias and national security.

Economic, social, and environmental transformations have brought the need for a reform of the State and its public administration to the center of the political agenda (Andion, 2012). The democratic and participatory regime was, for the most part (Uruguay, Brazil, Argentina, Ecuador, Mexico, and others), the prominent model of organization (Sen, 2000; Zaverucha, 2009). Thus, the 
political-administrative transformations of the first decade of the 2000s were carried out in the form of organizing the State, the national economy, and administrative practices through the public interest and its participation, which Sen called "the process of expanding freedoms" for enabling people to enjoy their political and civil liberties through participation, engagement, and social mobilization in political decisions. "[...] Public discussion and participation is thus central for the elaboration of policies in a democratic structure" (Sen, p. 170).

Although the 20th century was a period of exceptional achievements regarding the development and economic growth of Latin countries, especially in its last twenty years, as the end of that century approached, the countries faced problems (extreme poverty, for example) that they imagined they would overcome through the models and public policies implemented in the period. The enormous material and social triumphs achieved after the redemocratization of these countries were not enough to contain the return of neoliberal politics in this century (21st) to the center of leadership, highlighting the elaboration of administrative plans and reforms and the role of regulatory agencies and development models, as in vogue in Brazil - in addition to the impeachment and coup processes, when democratically elected presidents were overthrown. In other words, public interest, participation, and democracy are still a challenge for Latin countries (Paes de Paula, 2005).

In more recent years, new discussions such as the territorial and ecological exploration of development processes have been proposed as alternatives for promoting new styles and dynamics that are more sustainable and inclusive in terms of development (Lévesque, 2009; Sachs, 2009). The projects implemented by the State, which is the main development agent, are decisive for territorial development through promotion, integration, and planning of frontiers. Thus, the frontier has become an object of study for numerous researchers who seek to understand the development of these regions.

\section{How is the field of studies of public management and the development of border territories configured?}

We do not intend to mention all the projects implemented at the borders. The path was defined from our theoretical-methodological perspectives dialoguing with development theories. However, other paths are possible. Therefore, we analyzed the five main instruments ${ }^{9}$ used by researchers and politicians in the search for gaps ${ }^{10}$.

(a) Cross-border cooperation agreements: these agreements are understood as cooperation, which is the act of establishing strategic alliances between different actors and contiguous countries with the aim of stimulating and strengthening the regional integration process. Thus, crossborderization occurs when the different actions of actors (state and private) go further territorial limits and strengthen supranational integration (Carneiro Filho, 2016). The experiences implemented at the Brazilian BL aim to boost mainly the development of road, energy, and telecommunications infrastructure, international trade, migration, tourism, and the defense of the territory. Several procedures will legitimize a cooperation agreement, such as treaties, agreements, and consortia, among others. An example is the experience of the Intermunicipal Consortium (CIF, acronym in Portuguese) signed between the Brazilian cities of Barracão (PR) and Dionísio Cerqueira $\mathrm{SC}$ ) and the Argentine city of Bernardo de Irigoyen. It is a cooperation that seeks to manage the 
territory through the following four development strategies: education, tourism, agroecology, and local products. These strategies are created and established by the municipality's executive and legislative branches (Consórcio Intermunicipal de Fronteira, 2020). Angnes, Mattos, Klozovski and Sturm (2013) reported that a large part of the CIF's objectives has been or is being achieved. However, what caught their and our attention is that despite all the success, the "citizen participation", which even has space on the CIF institutional website, has no action presented or carried out.

(b) Public policies: In this second item, Krüger et al. (2017) identified and analyzed the main public policies for the development of the Brazilian BL. According to the authors, from the year 2000 onwards, most public policies were implemented and elaborated by the central government. They intend to promote the development and ordering of the region through the generation of employment and income, tourism, education, health, cultural activities, and preservation of the environment, besides policies to reduce crime and different trafficking. However, none of them deal specifically with social innovation. In the authors' analysis, the contrast between the discourse promoting sustainable development on the frontier and the actions implemented is striking, as there was no integration and balance between initiatives in various spheres, such as the environmental, economic, and social spheres. In contrast, the dimension associated with "economic development" was the one that presented the worst performance in the BL. Advances were observed in the dimensions of health and education, but the authors claimed that this evolution is a result of national policies, and not policies specific to borders. Finally, the authors revealed that most of the municipalities in the BL showed a decrease in indicators related to employment and income, in contrast, in this dimension, to the scenario observed in the country.

(c) Border Committees: Santo, Costa and Benedetti (2017) defined them as the third possibility as they represent a space for binational dialogue celebrated at the federal level and headed by the respective consul of each country. In this space, different actors (political, institutional, and private) can participate to discuss a local problem. Its focus is the local agenda, but this ends up being defined by the central government, as happened between Chile and Argentina, which established a committee with the objective of offering quick solutions for the transit of goods and the trafficking of people, vehicles, and goods. This was the same subject mostly addressed in the Brazil-Bolivia border committee. The importance of this agenda, which needs quick and efficient decisions, is indisputable. However, the use of public spaces for representation, negotiation, and consultation is essential to also allow for greater interaction between society, besides including more substantive agendas, such as education, environment, and health. Here, "participation", as reminded by Souza (2006), and the "so-called participatory experiences" are questioned because although decisions are local, they are still centralized in the various sectors of public administration (in this case, in the consul, the mayors and secretaries and, not infrequently, in some experts). That is, planning and public management are not democratized and the exercise of participation is mythologized.

(d) Isolated initiatives and specific projects in border zones: the studies based on them are inspired by theoretical approaches or prescriptive models to compare cities located in border zones (specific projects), with the predominance of a management and economic approach to the phenomenon of this instrument, such as the work carried out by Castro (2012). In the end, 
researchers only explain or detail a given project and try to compare them with other similar projects in other borders, so there is no depth of research.

(e) The empirical study of actors and their organizations: there are few works that will analyze the dynamics of development through the actions and practices of actors associated with the notion of territory, making use of a trustworthy understanding of territorial development, as we propose here. These are studies such as those by Costa e Costa (2015) and Conceição e Costa (2017), which are not defined by physical limits and focus on apprehending the production of social interaction within them, reporting how this determines life on the frontier.

Given this entire scientific and political scenario, we see that the field of public management studies in border territories follows the larger field of public administration, which is strongly marked by a functionalist conception of science (Andion, 2012), that is, these are studies that seek to produce scientific knowledge that is useful to maintain the status quo, seeking balance, social integration, order, and stability.

These findings indicate some gaps that can be addressed in this study, namely: (a) some border studies have been forging their importance over time, which gave this term the label of being "sectorized" for creating stereotypes of a region and reinforcing its marginalization when applied to the limits of the national state (Kaiser, 1998); (b) these studies confuse economic growth with development. However, the former goes further than the multiplication of material wealth - after all, growth is a necessary condition, but not sufficient (Sachs, 2009); (c) these studies constantly have a normative character of research, in which "the description of the elements that supposedly explain the performance of some areas ends up being taken for what it is not: an explanation of the causes" (Abramovay, 2006, p. 30), lacking a look at the citizens of the borders (the social actor).

All instruments previously commented are valid. However, they must give light to the main actor: the citizens of the border and their networks. Therefore, we will argue from the need to think on development and, subsequently, on a border management that values the heterogeneity of the border and microcivic and micropolitical activities aimed at the distribution of the powers (Cefaï, 2007) of border cities, in order to recognize and value organized civil society, encouraging its participation and allowing it to have an active voice in the public space.

\section{Amplifying the sense of frontier: the emphasis on actors}

Traditional border studies are a landmark of political geography, having as object the physical location of the boundary and its function of protecting the State sovereignty. These analyzes are diluted and the term frontier is analyzed with the concepts of territory, territoriality, sovereignty, power, and State (Bradshaw \& Gómez, 1999). The dispute over the geographical nature of the boundary becomes a demarcation of the field, through which researchers seek to apprehend the relationships, the social characteristics, the identities, and cultures of the different border regions. There is a great conceptual emphasis in their analyses, which sometimes leads these researches to some negligence due to creating border taxonomies, such as the border as the end of the State, or a territory exclusive for illegal activities (Lasconjarias, 2004).

Advances in research, as well as the development of social life, allowed frontier studies to acquire different conceptions in the contemporary world. The term frontier, which is of a legal 
nature and essential for the structure of national States, began to receive multiple approaches, such as that of interdisciplinarity, promoting the expansion of its scope. Today, cross-border cooperation, border committees, and border public management, among others, are discussed. However, such progress was not enough for the term not to be neglected (Benedetti, 2018).

The concept of frontier is constantly submitted to a deep discussion and resignification. From the studies by Lasconjarias (2004) to those by Benedetti (2018) we have a gap of fourteen years. During this time, despite advances, the neglect of research ended up creating metaphors referring to the concept of union, fraternity, and mobility, even proclaiming the "end of borders", with the justification that they only exist on maps (Hall, 2009).

This trivialization by researchers is caused by at least two factors. First, the intellectual trap they fall into when rushing to borrow models and concepts foreign to their own domain (Ramos, 1989). Second, the lack of ethics and methodological rigor when they try to explain the social aspect turning their backs on the ethos of science, seeking, in any case, to encapsulate the social aspect creating contexts and formulas to better translate (in their view) reality (Latour, 2012).

Grimson and Vila (2002) argued that, in the various attributions to the sense of frontier, "the actors" ended up being forgotten, as researchers romanticized the researches by obscuring the social and cultural conflict that frequently characterizes borders, regardless of the physical separation they present. The actor gained a vague, polysemic, and distorted conception, if not a black box concept in the social sciences (Gumuchian, Grasset, Lajarge, \& Roux, 2003). Such a position prevents asymmetric relationships between actors and States from being unveiled, which can mask and exclude some localities and phenomena. Some of the studies undertaken in border areas sometimes avoid the analysis of border conflicts and seek to reaffirm "regional integration", stating that people in these areas only demonstrate brotherhood and fraternity or the non-existence of "borders" for local populations.

For this reason, this generalized romanticism prevents the understanding of the meanings of frontier or limit. It prevents the capture of its political, economic, environmental, social, and cultural knowledge. Thus, the teaching on the frontier is prevented from being idealized. In this process of romanticization, the frontier became an instrument of disenchantment in the world, according to Max Weber, as some of the researchers and their normative researches concealed the history, knowledge, dilemmas, and challenges of populations living in the frontiers. They did not recognize the actors' perception of destiny - which is legitimate for them.

Therefore, we need to amplify the sense of frontier further the sectorial aspect without devaluing its existence. This does not imply abandoning it and deducing that it has lost place. It must be recognized that, nowadays, border areas have grown; some regions were revalued and began to be more influential for the economic, demographic, social, and cultural data of the 21st century, even further the limits of the territories, where now it is necessary to "cross borders" (Grimson \& Vila, 2002) under a perspective of territorial studies, and understand that they dialogue with phenomena that happen in other places considered as non-borders, such as the issue of immigration in large cities. The frontier should be integrated and seen as a space marked by varied activities that concentrate countless actors, and not be interpreted solely as the end of territory and space for illegal activities and smuggling (Santo, 2018). However, borders still have a residual place in public agendas and policies (Krüger et al., 2017). 
The problem is that, in very recent frontier studies, there is a general failure to pursue the theoretical possibility that the fragmentation of research might lead to the reinforcement of frontiers, rather than being an invitation to cross them. Thus, crossing borders rather than reinforcing borders is the preferred metaphor in the current hegemonic version of border studies and theory (Grimson \& Vila, 2002, p. 84).

Borders are zones or regions that have been moved and altered by space over time (Kaiser, 1998). In this concept, frontier studies present a major conceptual and theoretical problem. Initially, they all look similar-hence the label that qualifies the border as a marginal place that separates two or more countries. However, a micro analysis will reveal that they have specific and peculiar qualities and they also dialogue with macro problems or issues, which demands an empirical study of these locations, so that the social processes that arise there can be understood.

Border studies are currently the order of the day (Cardin \& Albuquerque, 2018; Costa \& Oliveira, 2012; Hall, 2009) and should remain so. The world history would be much better if it was seen from the border (Kaiser, 1998) - which leads us to the following border thought: how to conduct public management at the borders seeking to promote sustainable territorial development in these regions?

There is no exclusive recipe for this. However, border studies should focus on the actors, who constantly reconstruct the senses of border. When we emphasize the actor, we are returning the focus to action, which are the experience and territorialization processes. This argument had already been revived by Touraine (1984), who justified that it had once been hidden by various forces or ideologies of classical sociology, being later crushed by economic determinism. The actors' return aims at the transformation of a given order through the analysis of their practices.

Therefore, the analysis of social practices on the border must be immunized against a simplistic reading. We need an ontological and methodological vision that can allow us to vary the scale and interpret different interests and forces involved in the creation and formation of the frontier as a field of action. This requires undertaking research that takes into account their political ecology and that prioritizes the dynamic processes in which actors feel actively involved. It also requires studying agendas that do not have dialogue and understanding why local societies do not debate certain border issues, such as participation in local policies (Hall, 2009).

Kaiser (1998) indicated comparative studies for this analysis. Here, we present a more organic approach, so that we can re-discuss the practice of frontier studies and doing science in this field. Thus, given the serious socio-environmental and ethical problems we are experiencing, a pragmatist approach to frontiers and the search for new lifestyles and development seems opportune to us (Lévesque, 2009). However, it demands further research, crossing borders (Grimson \& Vila, 2002), valuing public participation, and integrating the territorial dimension to border development strategies. 


\section{Contributions of social innovation ecosystems, sustainability, and pragmatism to frontier studies}

We know that cities are globally interconnected through political, economic, social, environmental, and technical systems. Now, more than ever, scientific research and policies be united to idealize possible futures and overcome the challenges of connecting cities, valuing the ecological footprint and improving the health, education, and quality of life of their inhabitants. Therefore, studies on the emergence and effects of SIEs are intensifying, being identified as the main means of understanding that society has to drive global social transformation articulated to sustainability through governance, planning, management, and policy systems appropriate to the objective of promoting resilience in urban systems and a real impact on territorial development dynamics (Andion et al., 2020; Gómez-Baggethun et al., 2013; Lévesque, 2016; McPhearson et al., 2015).

The SIEs began to be thought under the influence of explanatory models of business (entrepreneurial) approaches, which illustrate the formation of entrepreneurial ecosystems (EE), an expression coined by George Tansley in 1935 to designate a complexity of interacting bodies that share a common destiny and whose interrelationships can result in some co-evolution. For Lévesque (2016) and Andion et al. (2020), the EE emphasizes entrepreneurship, which must be facilitated or retained by the community of members, placing at the center of the system not the company, but the entrepreneur as a leader, while the government's role is limited to that of facilitator. The question here is that the explanatory models arising from business approaches emerge to illustrate EEs, identifying a successful ecosystem - having a very limited operationalization when aimed at understanding SIEs as, among others, EEs prioritize the access to the market, human capital, finances, and ecosystem offers (support institutions), and do not consider some particularities, such as the trajectory (reasons for its emergence), structure, civil society, the need for a more active role of government (public policies), and the scenario and consequences (real and practical) of social innovations in the territory.

Therefore, more recent studies, such as the one by Andion et al. (2020) justified the need to build new theoretical-analytical approaches to understand existing problems, the social articulations that seek to resolve them, and how these actions contribute to improving resilience in cities. Inspired by these authors, we also start from the resumption of the pragmatist perspective ${ }^{11}$, which is based on different issues within the scope of collective action, reactivating the notion of public with conceptions in experience and in practice in order to understand the formation of SIES and their effects on the territory. Thus, the SIE is understood in this study as a technical device that allows mapping a network of actors, identifying their interactions and their field of action (environment, childhood, health, education, and others). Recognizing a SIE enables strengthening democratic experimentation, as the problematization and publication of a given disorder and the struggle for its solution becomes clear. In the words of Dewey (1939), it is about seeing democracy in practice.

Pragmatist researchers seek to understand methodologically different experiments that occur through test situations, crises, disputes, controversies, and different emergencies that drive collective engagement. That is, they seek to identify and explore the possibilities of new forms of political practice that demand a pragmatist analysis of microcivic and micropolitical activities in public laboratories (Ansell, 2012; Cefaï \& Terzi, 2012). This method of investigation is not intended 
to prove anything and does not try to decide anything. It only aims, in the case of science, to treat experience as a starting point for it to be revealed as it is, simply reality (Dewey, 1938).

Initially, the investigation seeks to capture collective action, that is, any attempt to constitute a group that is somehow formalized in a joint action or through dialogue, which will join efforts to produce a common good that will be freely accessible for everyone after its creation (Cefaï, 2007). It takes place in public arenas, a space for disputes and cooperation where there are people of good faith or not, and various games of interest. Its formulation is never guaranteed and will depend on an ongoing process of knowledge and evaluation of consequences. It is also configured temporally, without being possible to attribute established borders to it (Cefaï, 2009; Cefaï \& Terzi, 2012).

These issues are associated with emotional perception, feelings, and the memory of problematic situations, launching researches and organizing audiences (Quéré \& Terzi, 2015). Problematic situations (definition of the problem, for example, environmental disasters, tense meetings, poverty, inequalities, and pollution, etc.) and publicization (constitution of the public surrounding the problem) are inseparable from the fields of experience (Cefai \& Terzi, 2012). Their definition occurs through public investigation, which consists of configuration, definition, and control of a previously undetermined and vague situation in a determined situation.

The problematic situation arises when certain events are no longer necessary for the harmonious balance of collective life. There is a disarticulation in the social process and ways of life are broken, which leads to the formation of a public. Publics are associations, in the sense of connections (Latour, 2012). They are human and non-human ${ }^{12}$ organizations, movements, and groups affected by these breakdowns that end up getting involved in an attempt to resolve them. A problem only becomes public when it acquires a greater dimension, mobilizing different actors who intend to change a given situation and inscribe it in the public space, drawing the attention of different characters who confront the cause (Lascoumes \& Le Galès, 2012). Public problems are not those for which the government is responsible, but those that evoke the action of citizens around a problem (Dewey, 1927). They arise in the activity of identifying, problematizing, and disclosing a suffered situation (Quéré \& Terzi, 2015).

According to Dewey (1927), the formation of the public would also depend on the actions of the State and public institutions, whether through ensuring the conditions of freedom (freedom to associate and form the public), or the organization of public life in accordance with applicable policies or laws. Thus, recognizing the policies and laws of a problematic situation studied is a fundamental step in the process of public investigation, as it is through this apparatus that the State "tries" to maintain public order.

What makes this question even more intriguing to management theory and practice is the social experiment in which citizen participation has been mandatory. Social mobilizations around the social and environmental problems of cities have been analyzed in the form of social innovations, which begin to indicate intentional and targeted reconfigurations of social practices (Gómez-Baggethun et al., 2013). Thus, the researcher seeks to identify social innovation initiatives, laws, and policies that support innovation, as well as to understand how the experiences of these initiatives are promoted in the territory and produce consequences in the reinforcement of deliberative democracy and the promotion of a more sustainable style of development (Andion et al., 2020). 
According to Andion et al. (2017), social innovation is inscripted in long trajectories of configuration, which justifies the need to capture the experience of actors through investigation [inquiry] (Dewey, 1938), thus leading researchers to "follow" a partner, an associate or a network of actors to understand not only what they do, but how and why they do it over time (Latour, 2012). Here, the use of qualitative methods of observation of experiences and ethnographic work are highlighted. "The challenge of this proposal is to follow the experience of the actors in order to understand the processes of emergence and diffusion of social innovation, its scope, its consequences, and its limitation" (Andion et al., p. 382).

We see in this inscription that pragmatic analysis emerges as a way to renew public administration (Shields, 2008) by emphasizing the importance of public freedom and their engagement in solving problems and forming a democratic state (Dewey, 1927). The State is the place of experimentation. The experimentalism of pragmatism uses a prospective view of science. The goal is not to find eternal principles, but to use an experimental and ongoing process to develop action plans that are evaluated in light of practical consequences (Ansell, 2012). By moving away from a verifying perspective and prioritizing practical consequences (following an experimental or a scientific logic), this type of experimentalism can be a pillar in the construction of democracy, as it values public governance processes.

The emergence of democratic regimes revives the importance of freedom, which is the main feature of this model, and the appreciation of different forms of organization of individuals in associations (as opposed to individualism). For democracy to exist, concluded Dewey (1927), there is a need for free and voluntary collaboration and for individuals to have control over their own opinion. Therefore, democracy is associated with the free exercise of citizenship. The expansion and insurance of freedoms must also be fostered through (more) participation, whether by opening the doors of the government and giving space to public participation in decisions (for example, popular participation in urban planning and management) or by improving public policies, which should dialogue more with politics and look more at the territory.

\section{Cities and the frontier: giving visibility to public challenges}

In this section, we present a first technical survey on the SIEs on the Brazil-Bolivia border, identifying initiatives of social innovation and support, government agents, and other actors. Thus, we have reached out so far 212 plural organizations of individuals, groups, associations, politicians, companies, and others who share a collective identity.

Figure 2 shows in detail 113 social innovation initiatives, 25 government agents (city halls, secretariats, public prosecutor offices, and others), 64 teaching and research institutions ( 2 federal universities, 5 private universities, 2 master's programs, and 55 groups of research and extension), 6 public support institutions (bodies such as Sebrae, Senai, and Sesc that finance projects) and 4 support initiatives (private companies that finance projects through public notices, donations or internal projects, such as Vale, Votorantim, Camba, and Gravetal). Most of these organizations are concentrated in the urban area of the municipality of Corumbá (MS). However, several of them, are located in the countryside or in the Pantanal region (25 social innovation initiatives), since this border is home to the Pantanal, the largest wetland in the world. Ninety-six percent of the territory of Corumbá is located in the Pantanal, which covers 250,000 km², including Brazil (Mato Grosso and 
Mato Grosso do Sul), northern Paraguay, and eastern Bolivia. These initiatives in the Pantanal seek to support the nature (fauna and flora), river communities, families in rural settlements, other small producers, cowboys, and indigenous communities.

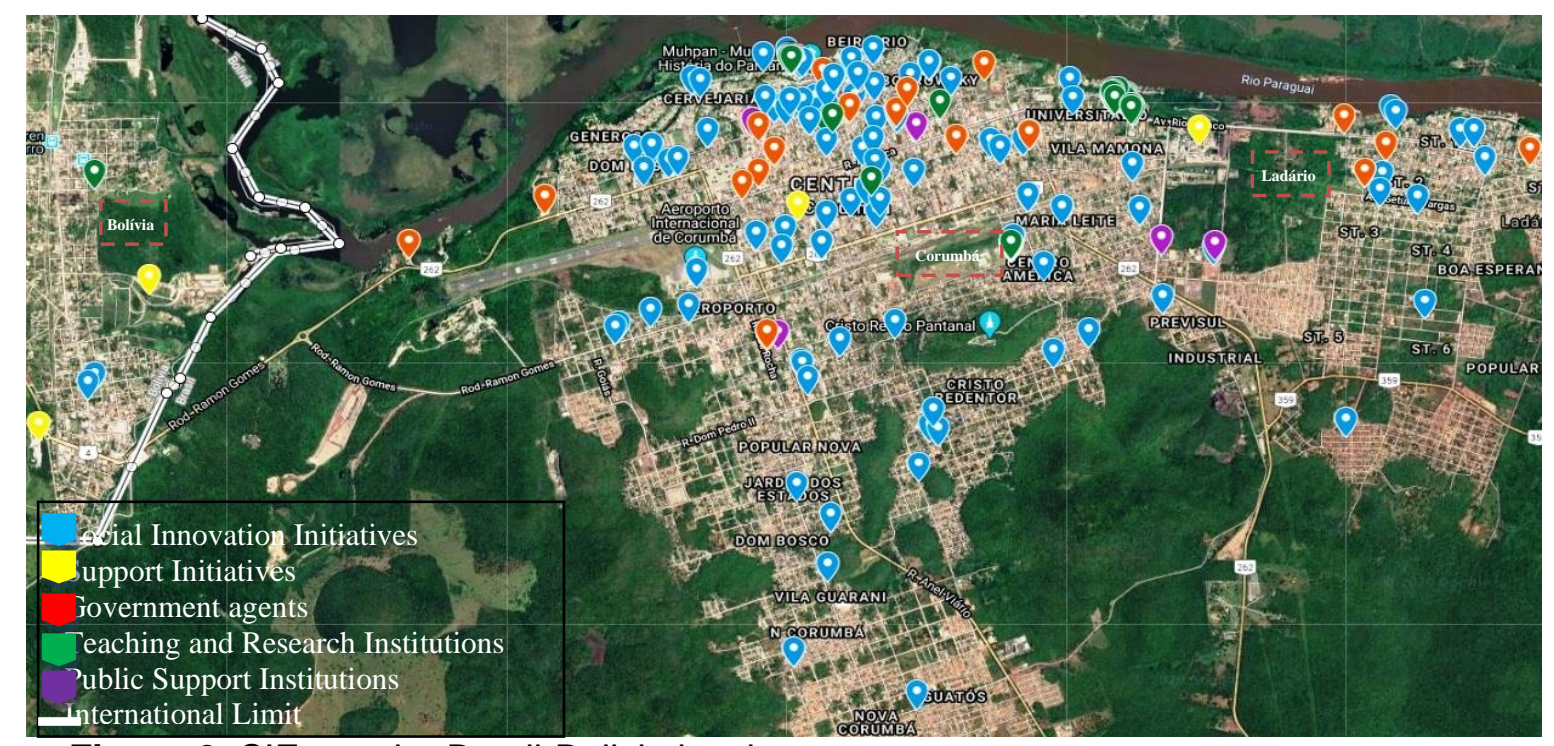

Figure 2. SIEs on the Brazil-Bolivia border

Source: Prepared by the authors.

Through this cartography, seven public problems that mobilize these different actors described in Table 1 on the Brazil-Bolivia border were identified. The nomenclature of these problems was inspired by the 17 SDGs (United Nations, 2015).

Table 1

\section{Identification of public problems}

\begin{tabular}{|c|c|}
\hline $\begin{array}{l}\text { Poverty } \\
\text { eradication }\end{array}$ & $\begin{array}{l}\text { The eradication of poverty and marginalization and the reduction of social inequalities is one of } \\
\text { Brazil's fundamental objectives, expressed in the Article } 3 \text { of the Federal Constitution (Brasil, } \\
\text { 1988). The State must promote the good of all, without prejudice of origin, race, sex, color, age, } \\
\text { and other forms of discrimination. The text is cohesive; } 86 \% \text { of Brazilians believe that Brazil's } \\
\text { development depends on reducing social inequalities (Georges, } 2019) \text {. However, poverty still } \\
\text { haunts the lives of Brazilians. Despite the achievements of the past, the numbers have grown } \\
\text { again and, today, } 13.5 \text { million Brazilians are miserable, that is, they live on less than US } \$ \\
1.90 / \text { day. In Mato Grosso do Sul, } 17 \% \text { of the population }(73,470 \text { thousand people) live in the } \\
\text { poverty line, with a per capita household income of } R \$ 385 \text {, and } 3 \% \text { live in extreme poverty (Frias, } \\
2019) \text {. There are eight favelas in the state, with five of them in Corumbá (MS), representing } 5,767 \\
\text { people (Souza, } 2019) \text {. On the Bolivian side, the situation is even worse, despite the progress that } \\
\text { the country has achieved in recent years. There are several challenges, such as access to } \\
\text { drinking water and sewage treatment, housing, food, and work, which are critical development } \\
\text { factors that call for social innovations and restructuring of public management with the } \\
\text { strengthening of governance by valuing community participation and empowerment approaches. }\end{array}$ \\
\hline $\begin{array}{l}\text { Social and } \\
\text { racial } \\
\text { vulnerability }\end{array}$ & $\begin{array}{l}\text { In Brazil, social inequality and poverty act as catalysts for gender inequalities and ethnic-racial } \\
\text { problems, creating socially, economically, and culturally marginalized groups. This situation } \\
\text { highlights the inefficiency of public power actions, with public policies that do not meet the }\end{array}$ \\
\hline
\end{tabular}




\begin{tabular}{ll}
\hline and gender & demands of the most vulnerable society. Thus, social vulnerability has been established as a \\
equality & major challenge for government officials, as new public policies need to be thought out, rethought, \\
& and specially operationalized and discussed with civil society. Violence and sexual exploitation of \\
& women and girls is a reality in this border area. From street prostitution to houses of prostitution, \\
& sex tourism is experiencing a "naturalization". The civil society, public authorities, the judiciary and \\
the police apparatus are aware of this activity. However, there are few established actions. \\
Exploited women suffer an intersectional action as, besides the gender issue, they are mostly \\
black and poor.
\end{tabular}

public health According to data from the Brazilian Institute of Geography and Statistics (IBGE, 2018), the and wellness mortality rate in Brazil is 6.6 per 1,000 births. In Corumbá and Ladário (MS), this rate more than doubles and reaches 17.8. On the Bolivian side, the numbers have decreased in recent years from 50 to 24 , but are still high. This difference is a powerful indicator of the problems that cities need to face in relation to health. Due to the significant cases of rabies and leishmaniasis, the challenges go further infant mortality and involve issues such as dengue, $\mathrm{H} 1 \mathrm{~N} 1$, abortion, cancer treatment, and animal health. Despite the high population (160 thousand inhabitants), many procedures are not performed in these cities, which depend on the municipalities of Campo Grande (MS) or Santa Cruz (Bolivia). The lack of a neonatal ICU and the limitations of Hemosul in dengue outbreaks indicate the need to rethink the epidemiological health surveillance services in border areas. The Integrated Border Health System (SIS-Fronteira) was created with the aim of improving these services, which have the intention of carrying out a diagnosis of local health and preparing an operational plan for the improvement of the network of health services in border municipalities (Krüger et al., 2017). Despite its benefits, this program has not yet been implemented in the region. Therefore, the challenges for different civil society initiatives range from demanding the operationalization of public policies to the distribution of goods and services in support networks.

\section{Ambiental degradation}

Environmental degradation is the entire process of destruction and removal of native vegetation, generating serious consequences for the fauna that lives in this habitat. This region has the two following large biomes: the Cerrado, which is the second largest biome in South America, with 5\% of the planet's biodiversity; and the Pantanal, one of the largest continuous wetlands on the planet (Ministry of the Environment, 2020). So much richness does not prevent the ills arising mainly from activities related to agriculture and mining. In 2019 , the Pantanal recorded $334 \%$ more fires than in the previous year. Consequently, the temperature increased by up to $6{ }^{\circ} \mathrm{C}$ while rainfall decreased by $25 \%$ (Oliveira, 2019). In March 2020, the fires tripled. Corumbá and Ladário (MS) lead the national ranking of fire outbreaks. The problem turned into a "conflict of neighbors" in which Brazilian and Bolivian mayors "blame" the fires on each other, as if the fire respected the international limit. Other disasters arise due to deforestation, wildlife trafficking, lack of solid waste management, and water pollution, remembering that this region does not have a sanitary landfill and the commitments for such implementation are slow ("Corumbá and Ladário sign a commitment to deploy a sanitary landfill", 2019). The BR-262, which is a highway that cuts through the Pantanal, is known as the "Highway of Death" due to the trampling of wild animals. There are, on average, 6 deaths/day and an estimated 3,000 deaths per year (Naujorks, 2018). For all these reasons, the shift towards sustainability is driven by heterogeneous approaches and initiatives from the network of civil society actors in the cities and their environmental concerns. Regarding this issue, micro actions dialogue with macro actions, as environmental change is of global interest.

Zero Hunger and Sustainable and Family Agriculture
Hunger in an agrarian state is an attention-grabbing practice. Hunger has increased worldwide, reaching 820 million people (Jarvis et al., 2019). Few studies provided a specific picture of this region. However, news regarding the child malnutrition of river peoples, indigenous peoples, and other groups (followed by death) are common. The Goal 2 of the SDG (United Nations, 2015) stipulated that by 2030 we should end hunger and ensure access for all people to safe, nutritious, and sufficient food throughout the year. For this end, it is necessary to value the production of family agriculture, indigenous peoples, and small fisher producers through access to land, credit lines, and public policies that strengthen the market, among others. There are only ten years left for the agreement to be fulfilled. Research shows that Brazil is unlikely to reach this goal and the increase in poverty is an indication (Favareto, 2019). According to Jarvis et al. (2019), small farmers are four-fold more likely to enter the poverty line compared to other individuals employed in different sectors of the economy. This region has approximately ten groups of producers, mostly settled, which have difficulties in expanding food production mainly due to lack of water and oppression by large producers. The transitions of the productive bases, with attention to nature, the appreciation of families, open markets, and programs that amplify the acquisition of family farming production are at the center of discussions to promote the development of the region and its interactions. 
Education and Current pedagogical trends have increasingly revealed an intercultural theoretical perspective. culture This trend seeks to create bonds of appreciation, acceptance, and respect for the most varied cultural manifestations, understanding that there are no superior or hierarchical cultural relationships, but a diversity that needs to be respected and understood. This intercultural perspective is fundamental to reduce gender or xenophobic prejudices through education. The cultural devaluation or depreciation is more evident in regions with great cultural flow, such as in this border, which presents social interactions between Brazilians, Bolivians, Paraguayans, Palestinians, indigenous peoples, and other peoples. This cultural flow, while creating hybridizations, also generates cultural prejudices. Therefore, schools in this region must act in order to promote intercultural relations, prioritizing integration by understanding life and opportunities on the frontier, valuing the sense of frontiers, bilingual education, and the formation of citizens able to live with diversity. Hence the importance of university extension projects to support schools in this endeavor, support initiatives to finance future projects, and other social innovation initiatives that also promote cultural and educational diffusion on the border.

Immigration The United Nations High Commission for Refugees (UNHCR) defines immigrants as everyone and Refugees who enters a country other than their country of origin for various reasons. On the other hand, refugees are "people who are outside their country because of a well-founded fear of persecution for reasons of race, religion, nationality, political opinion or participation in social groups and who cannot (or do not want) to return home" (UNHCR, 2018). This concept expands and encompasses, besides the reasons mentioned, people forced to leave their country due to armed conflicts, gender issues, violence, and massive violations of human rights. According to the UNHCR (2017), there are 258 million international migrants, 25.4 million of whom have left their country as a result of wars, violence, and persecution, which lead them to cross borders and become a refugee. In Brazil, 81,000 foreigners crossed the Brazil-Bolivia border in 2019; out of these, 56 thousand were tourists. Due to the proximity to Bolivia, traffic (coming and going) is constant due to the numerous exchange relationships. There are no border controls for the local population, which leads many immigrants to enter the country illegally. This certain "permissiveness" that favors local exchanges does not exclude xenophobia and racism, which demonstrates the social urgency of the cause of immigrants and refugees and its indispensability in the city.

Source: Prepared by the authors.

More than creating a typology of frontier cities, the cartography presented in Figure 1 allowed us to capture contexts of experience and action surrounding common problematic situations. Table 1 lists the challenges that the actors and networks seek to solve. The association of these actors does not follow a logic of action. They act in multiple worlds (Boltanski \& Thévenot, 2006). On the other hand, the formation of networks occurs due to proximity bonds. This proximity is not understood on a spatial scale, but in relation to what is experienced and to their daily lives, in which different public subjects are shared (Cefaï, 2009).

The different initiatives found have a complex network of cooperation and conflict focused on dealing with the public problem. In these relationships, a group of actors discusses their problematic situation, makes political agreements, and stages their public figures. It creates cultural universes, linking its image to the territory (symbol) and seeking to negotiate order and stabilize relationships. Logically, an initiative can act on more than one problem, such as the Moinho Cultural (eradication of poverty; social vulnerability, education, and culture). A more advanced study would be able to demonstrate whether these relationships configure the existence of different public arenas $^{13}$ (Cefaï, 2007).

It is possible to observe that all the public problems described in Table 1 are interconnected. For example, Demo (2002) argued that the problem of education, translated into learning, is of paramount importance for understanding the other (immigration) and promoting critical thinking (environmental degradation and poverty) and, when properly applied, can contribute to change the 
life of the student (hunger; vulnerability). Furthermore, the micro analysis of the problem, such as environmental degradation, reveals macro problems, as their causes and consequences impact present and future generations, besides being globally interconnected (air and ocean pollution, among others).

This first moment of identification of initiatives is called by the Obisf as "mapped" (see Figure 1), when the initiatives have enough information to be mapped or registered, as we did (Figure 2). They then go on to the "observed" stage, in which the initiatives have their information validated by the Obisf team (third stage of the research). We will carry out this stage from 2021 through the Center for Border Studies on Social Innovation, besides recognizing the laws and public policies by which the State seeks to promote the development of each problem. By analyzing the current information provided by different organizations, we realized that, like most cities in developing countries, social innovation initiatives are also mobilized around the most urgent issues and work with the most excluded audiences, such as the Association of Artisan Women from Barra do São Lourenço, located on the banks of the Paraguay River, in the Pantanal, who work with handicrafts made with water hyacinth, a plant native to the region; the Dyang (Puerto Quijarro), which provides assistance to women who are victims of sexual exploitation and trafficking; and the Guató Canoeiros Indian Association, which seeks to preserve the indigenous culture and tradition among the descendants of this ethnic group.

When we deepen the analysis in more specific networks, such as "education and culture", we realized in these two years (2019-2020) that organizations are articulated by proximity in public life. Their challenge is to awaken children and adolescents to be interested in culture and the importance of study, especially reading, for the formation of citizens (knowing how to think, discuss, and respect), as education and culture can contribute to fight poverty (Demo, 2002). The main target audience is Brazilian and Bolivian children and adolescents who are served, for example, by the network formed by the Moinho Cultural (music, dance, and arts for needy children) and other social innovation initiatives and support actors (Vale, TV Morena, UFMS, etc.). This articulation by proximity was also felt within a historical local tradition, the Carnaval, supported by the municipal and state government as "the biggest carnival in the Central-west region of Brazil". In Corumbá, different cultural and sports associations are linked to carnaval blocks or samba schools that have projects aimed at children and young people.

Some initiatives are linked to religious communities, acting mainly with spiritual and solidarity networks, distributing goods or community services for human and even environmental promotion. This is the case of Oficina Mãos Amigas (spiritist), which works with children and teenagers in the area of education and with neighborhood residents through training and income generation; the Comunidad Inmaculada Concepción (Catholic), which works in the education and care of needy children on the Bolivian side; the Desafio Jovem Peniel (evangelical), which promotes actions in the area of eradicating poverty and culture and the environment; and the Pastoral da Mobilidade Humana (Catholic), which has been working with the reception and insertion of immigrants and refugees.

Other initiatives are involved with conflicts surrounding urban and environmental planning, as well as objectives in the social, cultural, and economic fields. These experiences go further municipal boundaries, arguing and publicizing their challenges through vast repertoires, such as the SOS Taquari initiative, which works on the issue of the silting up of the Taquari River (more than 150 
$\mathrm{km}$ of silted river) and the Homem Pantaneiro Institute (IHP), which focuses on the conservation and preservation of the Pantanal biome, having already signed a partnership with the World Wide Fund (WWF) to promote, for example, training courses on the conservation and preservation of the Pantanal and the Cerrado. The challenge of these initiatives is huge, as the productive base of the Pantanal region is mainly focused on cattle raising, which is responsible for a large part of the burning of the Pantanal in 2020. The local discourse on environmental impacts focuses, above all, on economic loss and not on the quality of life, as in the case of the Taquari River. Therefore, as in the "education and culture" axis, the challenge of these initiatives is to preserve the environment and learning, enabling the population to understand the importance of nature, the harm caused by burning, and show that "everyone has the right to enjoy an ecologically balanced environment, which is a good for common use by the people and essential to the quality of life" (Brasil, 1988). Ensuring this right is everyone's duty.

So far, we have seen that pragmatism as a method contributes to the renewal of public administration (Shields, 2008), as it emphasizes the deliberations and negotiations necessary for society. The practice of democracy imagined by Dewey, as well as the participation and the notion of public, allows the reconnection of public administration to the action of actors, who constantly (re)define innovations in the city. Dewey $(1927,1939)$ emphasized education projects, as through them democracy begins within the classroom. Certainly, it is through education that a democratic process would begin, as in the case of our initiatives, we see that, besides the most immediate action (for example: hunger > giving food), the great challenge is to form critical, autonomous, and active individuals, who are ready to face the city's problems and challenges.

There are countless associations and articulations surrounding public problems in this region. Other initiatives and problems may exist and have not yet been identified by us. The SIE is a plural and endless network. It renews and is, thus, eternally provisional. The city is a laboratory so alive that it changes daily from every action. The network of actors comprising it moves and interacts and, in order to understand how social change occurs, and if it occurs, it is necessary to investigate and monitor and not to define the problem a priori. Many of these initiatives have already gained representation on a daily basis (such as the Network for Combating Cancer, Buraco da Onça Ecological Association, and others). Others continue to seek their own stabilization (such as the Quilombola Association, Different Generation, Aguapé Ecotourism, and others). There are different realities and purposes, which encourages the continuation of this research.

\section{To (not) conclude: the emergence of social innovation}

Who is interested in border studies? Is it just the people living in the border or everyone in the country? The border is a strategic area for the State. Brazil has the longest border strip in Latin America. However, it has great difficulties in perceiving the other and idealizing integration with Latin states. This study showed the need to assume the gaps found. However, there is difficulty to assume them in the face of the city's countless other challenges. Change requires a future project of social learning and adaptation, as well as recognizing that frontier cities function as complex, interdependent, and integrated systems.

The border is a space permeated by unique interculturality and heterogeneity, which are not considered when development plans are developed for the region. We, like any national public 
management, have to devise an alternative of seeing the world and acting on it - moving towards a new State-society relationship and thinking of a management model that escapes the traditional functionalist and normative conception (Andion, 2012), returning to a sociopolitical dimension of management (Paes de Paula, 2005), as we can no longer sustain naive assumptions based exclusively on instrumental rationality (attribute of the market system), which ends up misconfiguring the associated human life (Ramos, 1989). We have observed that the cross-cutting discussion to develop border areas is poorly addressed, and the idealized public policies do not involve the civil society in their elaboration and are far from promoting sustainable development for the region (Krüger et al., 2017).

Applying the contributions of pragmatism to border studies, especially John Dewey's considerations on democracy as association, research, and experimentation, allowed us to realize that border cities are full of plural organizations that act in a network of informal interactions facing different problems, thus comprising the SIE of the Brazil-Bolivia border. Network organizations arise due to the numerous test situations that make them operate in a political world (Boltanski \& Thévenot, 2006). They gain representation on a daily basis, offering numerous services to the city. In fact, these problems (Table 1) show the emergence of analyzing the SIEs at the border.

Therefore, the importance of recognizing the SIE for the democratic strengthening of border areas is opportune. If public policies are not working, then governments should appropriate more of the knowledge produced by the social and human sciences, in this case, the SIEs, which highlight what are the city's public problems and which organizations try to answer them, demonstrating, in the long term, the successes, challenges, and limitations of these responses. In a country as diverse and extensive as ours, public policies should not always be national in scope, but based on a local specificity, so that they can have a positive impact on people's lives.

Having this knowledge, public policies could be better developed or, in more ambitious terms, by identifying the practical consequences of the initiatives, we could re-discuss the role of public administration and idealize the "co-management of the city" (Ansell, 2012) through an object of public intervention, such as the "public policy forums" (Lascoumes \& Le Galès, 2012), a space for the democratic strengthening of cities where public action is negotiated between an ecosystem of actors who articulate their problematization in search of a project necessary to protect life, ensure rights, and increase ecological resilience within the city's strategic planning.

The experiences of projecting the city from participatory forums ${ }^{14}$ are still rare. We support that the feasibility of implementing a forum in this region and its possible contribution to the territorial integration of the border should be studied. In this space, the government and different civil society initiatives in both countries could give a multilateral approach to collective public problems, discuss public policies, and perhaps discuss the future institutionalization of the forum.

We reinforce, as qualified by Andion et al. (2020), that such theoretical-methodological choices generate advances in the understanding of the phenomena and limits in the scope of the study. Although the patchwork of a small conglomerate on the Brazil-Bolivia border does not expose the reality of other border areas, this case reinforces how much we need to qualify people's experience, practice, and political action in Latin America, where democratic experience is so fragile and recent. In other words, the contribution of this paper is to focus on the actors' practices (public 
action), aiming to uncap the border, expand its meaning, and enhance the actors' protagonism, contributing to the advancement of theorization on social innovations and border studies.

Studying the territory through the actor - their associations, engagements, and their collective action, represented through social innovations (practices that seek to change a given problematic situation) - encourages research to advance in order to understand how the participatory construction of public management takes place; the democratic dynamics of cities, the formation of public arenas, the importance of exercising citizenship, the scope and limits of social innovation, and its impact on the territory. The answer here is not given a priori, and this will be better studied by the Center for Border Studies on Social Innovation. When we rethink frontier studies, we do not exclude other forms of analysis and disciplines, nor the instruments of public management adopted so far. We are only discussing an alternative that is based on the worldview that emerges from practices, participation, and alternative development movements, such as gender, ecology, health, and education.

Our interdisciplinary research field of frontier studies, based on pragmatism, is a particular roadmap for conducting public investigations that will allow us to identify a range of teaching, research, and extension projects in this field, including quantitative, qualitative, and comparative research analyses. We believe that our proposals to provide access to social innovations can dialogue with other frontier cities and with broader projects, such as those conducted by the Obisf team, aimed at building urban resilience and inspiring theoretical discussions. Therefore, we decided not to conclude, leaving the door open for a beginning of research on social innovation, participation, and protagonism of actors in frontier cities.

\section{References}

Abramovay, R. (2006). Para uma teoria dos estudos territoriais. In M. Manzanal (Org.). Desarrollo rural: Organizaciones, instituciones y territorios (pp. 27-48). Buenos Aires: Ciccus.

Addor, F. (2018). Reflexões sobre democracia participativa na América Latina. Revista de Administração Pública,52(6), 1108-1124. doi:10.1590/0034-761220170131

Alto Comissariado das Nações Unidas para Refugiados [ACNUR]. (2017). Tendencias globales: Desplazamiento forzado en 2017. Genebra: Autor. Recuperado de https://bit.ly/2tdyc0p

Alto Comissariado das Nações Unidas para Refugiados [ACNUR]. (2018). Definição de imigrantes e refugiados. Recuperado de https://bit.ly/3jrAUus

Andion, C. (2012). Por uma nova interpretação das mudanças de paradigma na Administração Pública. Cadernos EBAPE.BR,10(1), 1-19. Recuperado de https://bit.ly/3hQHPMR

Andion, C., Alperstedt, G., \& Graeff, J. (2020). Ecossistema de inovação social, sustentabilidade e experimentação democrática: Um estudo em Florianópolis. Revista de Administração Pública,54(1), 181-200. doi:10.1590/0034-761220180418

Andion, C., Ronconi, L., Moraes, R., Gonsalves, A., \&Serafim, L. (2017). Sociedade civil e inovação social na esfera pública: Uma perspectiva pragmatista. Revista de Administração Pública. 51(3), 369-387. doi:10.1590/0034-7612143195 
Angnes, J. S., Mattos, S. M., Klozovski, M. L., \& Sturm, M. I. (2013). Consórcio intermunicipal da fronteira: Descrevendo as principais ações voltadas ao desenvolvimento regional a partir da perspectiva do poder público municipal. Revista de Administração Pública,47(5), 1165-1188. doi:10.1590/S0034-76122013000500005

Ansell, C. (2012). What is a democratic experiment? Contemporary Pragmatism,9(2), 159-180.doi:10.1163/18758185-90000235

Benedetti, A. (2018). Claves para pensar las fronteras desde una perspectiva geográfica. Geousp - Espaço e Tempo,22(2), 309-328. doi:10.11606/issn.21790892.geousp.2018.133707.

Boltanski, L.,\& Thévenot, L. (2006). On justification: Economies of worth. Princeton: Princeton University Press.

Bradshaw, R.,\& Gómez, R. L. (1999). Fronteras: Una visión teórica en el período contemporáneo. Aldea Mundo,4(7), 14-19. Recuperado de https://bit.ly/34jnAzn

Brasil. (1988/2016). Constituição da República Federativa do Brasil: Texto constitucional promulgado em 5 de outubro de 1988, com as alterações determinadas pelas Emendas Constitucionais de Revisão nos 1 a 6/94, pelas Emendas Constitucionais nos 1/92 a 91/2016 e pelo Decreto Legis/ativo no 186/2008. Brasília, DF: Senado Federal.

Cardin, E. G.,\& Albuquerque, J. L. (2018). Fronteiras e deslocamentos. Revista Brasileira de Sociologia,6(12), 114-131. doi:10.20336/rbs.236

Carneiro Filho, C. P. (2016). Fronteiras irmãs: Transfronteirizações na Bacia do Prata. Porto Alegre, RS: Editora da UFRGS.

Castro, E. (2012). Expansão da fronteira: Megaprojetos de infraestrutura e integração sulamericana. Caderno CRH,25(64), 45-61.doi:10.1590/S0103-49792012000100004

Cefaï, D. (2007). Porquoi se mobilise-t-on? Les théories de l'action collective. Paris: La Découverte.

Cefaï, D. (2009). Como nos mobilizamos? A contribuição de uma abordagem pragmatista para a sociologia da ação coletiva. Revista de Estudos de Conflitos e Controle Social,2(4), 11-48. Recuperado de https://bit.ly/34gYfGe

Cefaï, D.,\& Terzi, C. (2012). L'expérience des problèmes publics. Paris: Perspectives Pragmatistes.

Cepal prevê aumento da pobreza na América Latina e Caribe em 2019 (2019, 29 de novembro). ONU News. Recuperado de https://bit.ly/2SvpZ7i

Conceição, C. A., \& Costa, E. A. (2017). O principiar da agroecologia na fronteira oeste de Mato Grosso do Sul. Trabalho apresentado no 8o Simpósio Internacional de Geografia Agrária e 9o Simpósio Nacional de Geografia Agrária, Curitiba, PR. Recuperado de https://bit.ly/3hPrWXO

Consórcio Intermunicipal de Fronteira (2020). Recuperado de https://bit.ly/3rja5tw 
Corumbá e Ladário firmam compromisso para implantar aterro sanitário. (2019, 10 de maio). Jornal Diário Corumbaense. Recuperado de https://bit.ly/2Tj0zue

Costa, E. M.,\& Costa, E. A. (2015). Governança territorial em áreas de fronteira. Trabalho apresentado no 7o Seminário de Estudos Fronteiriços. Corumbá, MS. Recuperado de https://bit.ly/3i7WIQD

Costa, G. V., \& Oliveira, M. A. (2012). Mestrado interdisciplinar em estudos fronteiriços/UFMS: perspectivas, discussões e pesquisas. Revista NUPEM,4(6), 27-44. Recuperado de https://bit.ly/3ulxPOv

Demo, P. (2002). Educação e desenvolvimento. Campinas, SP: Papirus.

Dewey, J. (1927). The public and its problems. Chicago: Swallow.

Dewey, J. (1938). The theory of inquiry. New York: Holt, Rinehart \& Wiston.

Dewey, J. (1939). Democracia criativa: A tarefa diante de nós. Recuperado de https://bit.ly/2WLLP6A

Favareto, A. (2019). A dimensão territorial do desenvolvimento brasileiro recente e os vetores de uma transição ecológica nos marcos da Agenda 2030. IGEPEC.33(1), 172-190. doi:10.48075/igepec.v23i0.22752

Frias, S. (2019, 6 de novembro). Em MS, 3\% da população vive na extrema pobreza. Campo Grande News. Recuperado de https://bit.ly/3yHikDy

Georges, R. (2019). Nós e as desigualdades: Pesquisa Oxfam Brasil/DataFolha: Percepções sobre desigualdades no Brasil. São Paulo, SP: Oxfam Brasil. Recuperado de https://bit.ly/34okdql

Gómez-Baggethun, E., Barton, A., Langemeyer, J., McPhearson, T., O’Farrell, P., Andersson, E., ... Kremer, P. (2013). Urban ecosystem services. In T. Elmqvist, M. Fragkias, J. Goodness, B. Güneralp, P. J. Marcotullio, R. I. McDonald, ... C. Wilkinson (Eds.), Urbanization, biodiversity and ecosystem services: Challenges and opportunities a global assessment(pp. 175-251). Dordrecht: Springer.

Grimson, A.,\& Vila, P. (2002). Forgotten border actors: The border reinforcers. Journal of Political Ecology,9(1), 69-88. doi:10.2458/v9i1.21635

Gumuchian H., Grasset, E., Lajarge, R.,\& Roux, E.(2003). Les acteurs, ces oubliés du territoire. Paris: Anthropos.

Hall, T. (2009). Puzzles in the comparative study of frontiers: Problems, some solutions, and methodological implications. American Sociological Association,24(1), 25-47. doi:10.5195/jwsr.2009.332

Instituto Brasileiro de Geografia e Estatística [IBGE]. (2018). IBGE Cidades - Corumbá. Panoramas. Recuperado dehttps://bit.ly/2ZEoZzK

Jarvis, A., Loboguerrero, A. M., Martinez-Baron, D., Prager, S., Ramirez, J., Eitzinger, V. A., . . . Tarapues, J. (2019). Situación rural de América Latina y el Caribe con 2 grados de calentamiento. 2030 - Alimentación, agricultura y desarrollo rural en América Latina y el 
Caribe, No. 10. Santiago do Chile: Organización de Las Naciones Unidas para La Alimentación y la Agricultura. Recuperado de https://bit.ly/3upKPSO

Kaiser,W. (1998). Penser la frontière - notions et approches. Histoire des Alpes - Storia delle

Alpi-Geschichte der Alpen,1(3), 63-74.Recuperado de https://bit.ly/3yzj79L

Kleba, M. E., Comerlatto, D.,\& Frozza, K. (2015). Instrumentos e mecanismos de gestão: Contribuições ao processo decisório em conselhos de políticas públicas. Revista de Administração Pública,49(4),1059-1079. doi:10.1590/0034-7612125666

Krüger, C., Dantas, M. K., Castro, J. M., Passador, C. S.,\& Caldana, A. C. (2017). Análise das políticas públicas para o desenvolvimento da faixa de fronteira brasileira. Ambiente \& Sociedade,20(4), 41-62.doi:10.1590/1809-4422asoc0005r1v2042017

Lasconjarias, G. (2004). Délimiter la frontières. Hypothèses,1(8), 77-84. doi:10.3917/hyp.041.0077

Lascoumes, P.,\& Le Galès, P. (2012). Sociologia da ação pública. Maceió, AL: Edufal.

Latour, B. (1994).Jamais fomos modernos: Um ensaio sobre antropologia simétrica. São Paulo, SP: Editora 34.

Latour, B. (2012). Reagregando o social: Uma introdução a teoria ator-rede. São Paulo, SP: Edusc.

Lévesque, B. (2009). Economia plural e desenvolvimento territorial na perspectiva do desenvolvimento sustentável: Elementos teóricos de sociologia econômica e de socioeconomia. Política \& Sociedade,8(14), 107-144.doi:10.5007/21757984.2009v8n14p107

Lévesque, B. (2016). Économie sociale et solidaire et entrepreneur social: Vers quels nouveaux écosystèmes? Reveue Interventions Économiques,54(1), 1-45. doi:10.4000/interventionseconomiques.2802

Lipietz, A. (1991). Audácia: Uma alternativa para o século 21. São Paulo, SP: Nobel.

Machado, L. O. (1998). Limites e fronteiras: Da alta diplomacia aos circuitos da ilegalidade. Revista Território. 8(1), 9-29.

McPhearson, T., Andersson, E., Elmqvist, T.,\& Frantzeskak, N. (2015). Resilience of and through urban ecosystem services. Recuperado de https://bit.ly/2MAkhNg

Ministério do Meio Ambiente. (2020). Biomas. Recuperado de: https://bit.ly/3AdIL5B

Naujorks, J. (2018, 20 de novembro). 'Rodovia da Morte': Seis animais morrem atropelados por dia na BR-262 que cruza o Pantanal de MS. G1. Recuperado dehttps://glo.bo/3cm54bz

Oliveira, E. (2019, 12 de setembro). Pantanal registra 334\% mais focos de queimadas em 2019, ano com menos chuvas e intensa onda de calor na região. G1. Recuperado de https://glo.bo/2wGDKWi 
Oliveira, S., Pêgo, B., Moura, R., Krüger, C., Nunes, M.,\& Moreira, P. (2017). Fronteiras do Brasil: Uma síntese dos trabalhos da oficina de Brasília. Brasília, DF: Instituto de Pesquisa Econômica Aplicada.

Organização das Nações Unidas. (2015). Agenda 2030. 17 objetivos para transformar o mundo. Recuperado de https://bit.ly/3hhgDoH

Paes de Paula, A. P. (2005). Por uma nova gestão pública. Rio de Janeiro, RJ: Editora FGV.

Quéré, L.,\& Terzi, C. (2015, 23 de fevereiro).Pour une sociologie pragmatiste de l'expérience publique. SociologieS,Dossiers. Recuperado de https://bit.ly/3fKMdKx

Ramos, A. G. (1989). A nova ciência das organizações: Uma reconceituação da riqueza das nações. Rio de Janeiro, RJ: Editora FGV.

Sachs, I. (2009). Caminhos para o desenvolvimento sustentável. Rio de Janeiro, RJ: Garamond.

Santo, A. L. (2018). O uso de fotografias e vídeos em pesquisa qualitativa: em busca de um novo olhar sobre os territórios fronteiriços. Revista ADM.MADE, 22(2), 3-34. doi:10.21714/2237-51392018v22n2p013034

Santo, A. L., \& Andion, C. (2020). Imigração e cidades: uma cartografia da arena pública de apoio aos imigrantes e refugiados em Florianópolis. Interações, 21(2), 1-23. doi:10.20435/inter.v21i4.2717

Santo, A. L., Costa, E. A., \& Benedetti, A. (2017). Possibilidades de gestão compartilhada de territórios fronteiriços: Reflexões a partir das feiras livres de Corumbá, Brasil. Revista Espacios, 38(17), 30-45. Recuperado de https://bit.ly/3yHzrVO

Sen, A. (2000). Desenvolvimento como liberdade. São Paulo, SP: Companhia das Letras.

Shields, P. M. (2008). Rediscovering the taproot: Is classical pragmatism the route to renew public administration?.Public Administration Review,68(2), 205-221. doi:10.1111/j.15406210.2007.00856.x

Souza, M. L. (2006). A prisão e a ágora: Reflexões em torno da democratização do planejamento e da gestão das cidades. Rio de Janeiro, RJ: Bertrand Brasil.

Souza, P. N. (2019, 10 de dezembro). Cruzar a fronteira Brasil-Bolívia por Corumbá. Campo Grande News. Recuperado dehttps://bit.ly/3oYIn4L

Touraine, A. (1984). O Retorno do Ator. Lisboa: Instituto Piaget.

Wolfram, M.,\& Frantzeskaki, N. (2016). Cities and systemic change for sustainability:

Prevailing epistemologies and an emerging research agenda. Sustainability,8(144), 1-18. doi:10.3390/su8020144

Zaverucha, J. (2009). Fragilidade da democracia e do Estado de direito no Brasil. In J. A. T. Santos (Org.), Democracia, violência e lutas sociais na América Latina (pp. 47-66). Porto Alegre, RS: Editora da UFRGS. 


\section{Financing}

This study was financed in part by the Coordenação de Aperfeiçoamento de Pessoal de Nível Superior - Brasil (CAPES) - Finance Code 001

\section{Acknowledgement}

We would like to thank the team at the Observatory of Social Innovation of Florianópolis (Udesc) for their research and contribution to the subject. We are grateful for the dialogue with Professor Vivian Veiga from the Federal University of Mato Grosso do Sul and researcher at Neisf. Her statements were/are fundamental for the construction of this project.

\section{Notes}

1. This term is also found as "border territorial development", or "border zones". Zone, in the sense of a strip that concentrates inhabitants, housing, leisure, education, economic activities, and etc. Here we opted for BTD, dialoguing with the paradigm of territorial development.

2. Open access portal of Brazilian universities on limits and borders. See: https://bit.ly/2ztlAam

3. It refers to the issue of immigrants and refugees. In 2019, the construction of the wall on the US-Mexico border began, besides the invisible wall constituted by the barriers that countries impose on countless people who try to enter their territories when fleeing poverty, violence, and persecution, as happens in Europe.

4. This paper perceives the frontier based on the studies by Nogueira (2007), specifically the "lived frontier" - a type of frontier that has more meaning for the society living on the frontier, as it reflects and refers to their daily lives. Nogueira, R.J.B. (2007). Border: Identity reference space? Revista Ateliê Geográfico, 1(2), 27-41.doi:10.5216/ag.v1i2.3013

5. However, in Brazil, until this study was completed, social innovation is still not an issue addressed in frontier zones. This research gap motivated this study.

6. This paper is part of a series of research carried out by the Center for Social Innovations in the Public Sphere over the past 10 years. Retrieved from https://bit.ly/30nYcXr. For more details on Obisf, see Andion et al. (2020).

7. The Border Strip is $\mathbf{1 5 0} \mathrm{km}$ wide parallel to the national territory's terrestrial dividing line. It arose from Law No. 6,634/1979, regulated by Decree No. 85,064/1980, the content of which was ratified by the Federal Constitution of 1988, in $\S 2$ of Article 2: "Registration of Brazilian municipalities with an area wholly or partially located in the Border Strip".

8. Concept used in mobile telephony related to data transmission (sending and receiving) through mobile networks, in this case without international limits or international charging.

9. We understand "public management instruments" as qualified by Kleba, Comerlatto, and Frozza (2015), as follows: "guidelines and parameters established in documents, such as laws, policies or plans, which constitute instruments to guide and qualify the democratic management of public policies" (p. 1059). 
10. The analysis of this stage was inspired by the study by Ricardo Abramovay (2006) to categorize the works that associate the frontier with territorial development.

11. For further details, we suggest: Corrêa, D., \& Dias, R. (2016). Crítica e os momentos críticos: De la justification e a guinada pragmática na sociologia francesa. MANA, 22(1), 67-99. doi:10.1590/0104-93132016v22n1p067

12. For Latour (1994, 2012), reality is considered as dynamic; being complex and non-linear. Hence the need to accompany the subjects to understand nature as it is seen, perceived, experienced, and interpreted by the actor. "Actor-network" refers to a compound of humans and nonhumans (technologies, organizations, animals, lists, reports, and others) who express themselves through guidelines, manuals, and spokespersons. The actor-network is not the same as an "actor network". The actor-network indicates the set of everyone who promotes an action.

13. For further details on the formation of public arenas, read: Cefaï, D. (2002). ¿Qué es una arena pública? Algunas pautas para un acercamiento pragmático. Retrieved from https://bit.ly/34XIbZK

14. One of these experiences is the Public Policy Forum of Florianópolis. Visit: https://bit.ly/2VNgs9U

\section{Authorship}

\section{Anderson Luís do Espírito Santo}

Doctor in Administration from the Santa Catarina State University (Udesc). Master in Border Studies from the Federal University of Mato Grosso do Sul (UFMS). Professor of the Administration course at UFMS, Campus do Pantanal. Researcher at the Center for Border Studies on Social Innovation (UFMS) and at the Center for Social Innovations in the Public Sphere (Nisp-Udesc).

E-mail: anderson84luis@gmail.com

ORCID: http://orcid.org/0000-0001-6507-974X

\section{Douglas Voks}

Doctor and Master in History from the Santa Catarina State University (Udesc). Professor of the History course at UFMS, Campus do Pantanal. Researcher at the Center for Border Studies on Social Innovation (UFMS).

E-mail: douglas_voks@hotmail.com

ORCID: https://orcid.org/0000-0002-7725-4389

\section{Conflict of interests}

The authors inform that there is no conflict of interest. 


\section{Author contributions}

First author: design (leader), data curation (equal), formal analysis (equal), investigation (equal), methodology (leader), project administration (equal), resources (equal), supervision (leader), validation (equal), preview (equal), writing - original draft (equal), writing - proofreading and editing (equal).

Second author: design (support), data curation (equal), formal analysis (equal), investigation (equal), methodology (support), project administration (equal), resources (equal), supervision (support), validation (equal), preview (equal), writing - original draft (equal), writing - proofreading and editing (equal).

\section{Plagiarism check}

The O\&S submits all documents approved for publication for plagiarism verification using a specific tool.

\section{Data availability}

The O\&S encourages data sharing. However, out of respect for ethical dictates, it does not require the disclosure of any means of identification of research participants, fully preserving their privacy. The practice of open data seeks to ensure the transparency of research results, without revealing the identity of the research participants.

O\&S is a signatory of DORA (The Declaration on Research Assessment) and COPE (Committee on Publication Ethics). 